\title{
Allelopathic influence of some fruit tree leaf extracts on germination and seedling development of different weeds and vegetable crops
}

\author{
Matheus Ferreira França Teixeira ${ }^{1}$, Daniel Teixeira Pinheiro ${ }^{1 *}$, Hamilton Carvalho Santos Junior ${ }^{1}$, Ediane \\ Conceição Alves ${ }^{1}$, Tiago Teixeira Viana Barros ${ }^{1}$, Marco Antônio Moreira de Freitas ${ }^{2}$, Denise Cunha Fernandes \\ dos Santos Dias ${ }^{1}$
}

\author{
${ }^{1}$ Departamento de Fitotecnia, Universidade Federal de Viçosa, Av. PH Rolfs s/n, Viçosa, Minas Gerais, Brazil \\ ${ }^{2}$ Departamento de Ciências Agrárias, Instituto Federal Goiano, Rodovia Geraldo Silva Nascimento, Km 12,5 , Urutaí, \\ Goiás, Brazil
}

*Corresponding author: pinheiroagroufv@gmail.com

\begin{abstract}
Allelopathy is an important mechanism by which plants release allelochemicals. This study aimed to evaluate and compare the allelopathic effect of extracts of fruit tree leaves (orange, mango, jabuticaba and guava trees) on the germination and seedling development of different weeds (morning glory and beggartick) and vegetable crops (lettuce and cabbage). The FGC and G were evaluated. After germination, SDM and SL were measured. In general, first germination counting (FGC) and G (germination) were decreased for all species conducted with the allelopathic extracts in relation to the control. Mango extract reduced the FGC of morning glory in 20 p.p.m. The $\mathrm{G}$ of beggartick reduced to $0 \%$, while cabbage and lettuce germination was not affected. The highest reduction on FGC was observed in lettuce using jabuticaba extract, usinf 9 p.p.m, compared to the control. The extracts reduced the $\mathrm{G}$ of morning glory and beggartick, respectively, in between 5 and 11 p.p. Jabuticaba extract reduced significantly the $G$ of morning glory and beggartick. The development of morning glory and beggartick was negatively affected by allelopathic extracts. The $\mathrm{G}$ of morning glory and beggartick is affected by the jabuticaba extract. The development of cabbage seedling was affected when all extracts were used and guava extract affected the length of cabbage seedlings. Mango extract has potential to control morning glory and beggartick in established lettuce and cabbage fields. Mango, orange, jabuticaba and guava extracts have the potential to control weeds on lettuce established fields. Guava extract is not indicated to control weeds on cabbage cultivated fields.
\end{abstract}

Keywords: Allelopathy, Control, Effects, Seeds, Species, Vigor.

Abbreviations: FGC_First germination counting; G_Germination; SDM_Seedling dry matter; SL_Seedling length; p.p._percentage points.

Introduction

Competition between plants occurs in certain environments mainly because of water, nutrient and light limited resources (Antonelli et al., 2016). In this context, plant-weed competition is a major obstacle to crop production and expansion.lt changes not only crop dynamics, but composition, biodiversity and crop yield potential (Bajwa et al., 2016). Aiming to control weeds and reduce competition with cultivated plants as much as possible, some strategies have been constantly used, including chemical and mechanical control (Smith et al., 2011; Chauvel et al., 2012). However, these methods present some challenges such as cost, labor, and environmental impact, due to excessive herbicide use. Thus, it is important to use alternative methods, such as allelopathy (Jabran et al., 2015). Regarding competition, allelopathy is an important mechanism in which plants release chemical compounds named allelochemicals (Sharokhi et al., 2011). Allelochemicals can cause direct or indirect and positive or negative results to other plants and organisms (Krenchinski et al., 2017). By releasing the allelochemicals, plants can inhibit the germination and development of other species. They can regulate the microbial soil community, reduce the attack of pests and diseases, enhance physical and chemical soil characteristics, besides performing other strategies, aiming to reduce competition and enhance plant yield (Pedrol et al., 2006, Grisi et al., 2012). In this context, several species can have allelopathic effect on weed and present sustainable potential to control those plants (Islam and Kato-Noguchi, 2012; Zeng, 2014). However, it is important to emphasize that these effects are not restricted to weeds, but to all plants cultivated in the local environment. Many studies evaluate the use of allelopathic extracts in weed control (Khaliq et al., 2013; Kilic \& Vaizogullar, 2016; Glab et al., 2017). However, only a few report their effects on cultivated species. Therefore, evaluating the allelopathic effects on weeds and vegetable 
crop species has become an important part of the planning of crops to be planted under consortium system or in environments where these substances are being used (Bezerra et al., 2007). Following Said and Yusoff (2014), allelochemicals can be released in the environment by volatilization, leaching and exudation through roots or decomposition of different plant organs. However, for most species, the allelopathic effect is more evident when leaf extract is used (Turk and Tawaha, 2003).

Therefore, this paper aimed to evaluate and compare the allelopathic effect of fruit tree leaf extracts on germination and seedling development of different weeds and vegetable crops.

\section{Results and Discussion}

\section{Electric conductivity of allelopathic extracts}

There was no significant difference between the osmotic potentials regarding water and extracts (Table 1 ). Thus, the observed effects on germination and seedling development, for the different species, are due to the intrinsic character of the extracts, without any relation to water deficit. Water deficit can be caused by the presence of salts and other inert materials in the solution, which culminates in reduced osmotic potential (Blum, 2011). Adversely to the results observed in this study, Han et al. (2008) acknowledged the allelopathic effects of ginger aqueous extract on osmotic potential reduction, which affects soybean and chive germination.

\section{Germination test}

In the first germination counting (FGC), significant reduction was observed for all species conducted with the allelopathic extracts in relation to the control treatment. The mango extract reduced the FGC of morning glory in approximately 20 percentage points (p.p.). The germination of beggartick reduced to $0 \%$, while cabbage and lettuce germination was not affected (Fig. 1).

According to El-Rokiek et al. (2010), mango leaves hold different acids, such as caffeic, feluric, coumaric, benzoic, and other compounds that can have herbicide effects on other plants.

The negative guava effects on FGC were observed on morning glory and cabbage in relation to the control treatment, although not affecting beggartick and lettuce (Fig. 1). Concerning the cultivated species, the highest reductions on FGC were observed in lettuce, especially when using jabuticaba extract, with 9 p.p reduction in relation to the control. The orange extract caused similar effects on lettuce and cabbage, with significant reduction in FCG in relation to the control treatment on both species (Fig. 1). According to Tsai (2008), monoterpene limonene is the compound mainly responsible for the allelopathic effects present in orange essential oil.

Regarding germination (G), all the species presented significant reduction when allelopathic extracts were used. The extracts reduced the germination of morning glory and beggartick, respectively, in between 5 and 11 p.p. and 45 p.p.
The jabuticaba extract reduced significantly the germination of morning glory and beggartick, but did not affect lettuce germination in relation to the control treatment (Fig. 2). Therefore, this extract has potential to be used on lettuce fields to control these weeds.

Regarding a plant of the Myrtaceae family, the probable allelopathic effect of jabuticaba is related to the presence of terpenes in the essential oil (Imatomi et al., 2013). Enzyme inhibition is another important process through which allelochemicals can affect germination. The enzymes affected can be $\partial$-amilase, lipases, and enzymes of the antioxidant system, following the effects observed on lettuce (KatoNoguchi and Macías, 2005); soybean (Han et al. 2008) and morning glory (Pergo and Ishii-Iwamoto, 2011) seeds.

\section{Seedling development}

With respect to germination, the development of morning glory and beggartick seedlings was negatively affected by the allelopathic extracts. The effects on morning glory were enhanced when the jabuticaba extract was used. On the other hand, the effects on beggartick were increased when orange and guava extracts were used (Fig. 3). Krenchinski et al. (2017) carried out a similar study on the effect of Cymbopogon citratus extract on the germination and germination speed of beggartick. Reduced plant development will consequently affect carbohydrate concentration, as they are produced by the photosynthetic process (Currey and Lopez, 2015).

Lettuce seedling development was not affected by the use of allelopathic extracts. Thus, any of the extracts in this research can be used in fields cultivated with lettuce, where the seedlings are already established. Concerning dry matter, the development of cabbage seedling was affected when all extracts were used. However, the guava extract affected the length of cabbage seedlings, which can be detrimental to yield. Thus, it is not recommended in fields with this specie (Fig. 3). Besides the compounds mentioned in this study, saponins, phenols and benzoic acid can reduce germination and the seedling development of different species (Batish et al., 2007, Shahrokhi et al., 2011).

\section{Materials and Methods}

\section{Location and plant material}

The study was conducted in 2015, in the department of Plant Science (Fitotecnia) of the Universidade Federal de Viçosa, Minas Gerais State, Brazil. It was evaluated the germination and seedling development of different species under the effect of the allelopathic leaf extract from orange (Citrus sinensis L.), mango (Mangifera indica L.), jabuticaba (Myrciaria cauliflora Berg) and guava (Psidium guajava L.) trees.

\section{Allelopathic extract preparation}

From each fruit tree species, $200 \mathrm{~g}$ of leaves were weighed, macerated and added to $1000 \mathrm{~mL}$ of distilled water in an industrial blender. The macerate was filtered with the use of a 
Table 1. Treatment osmotic potential.

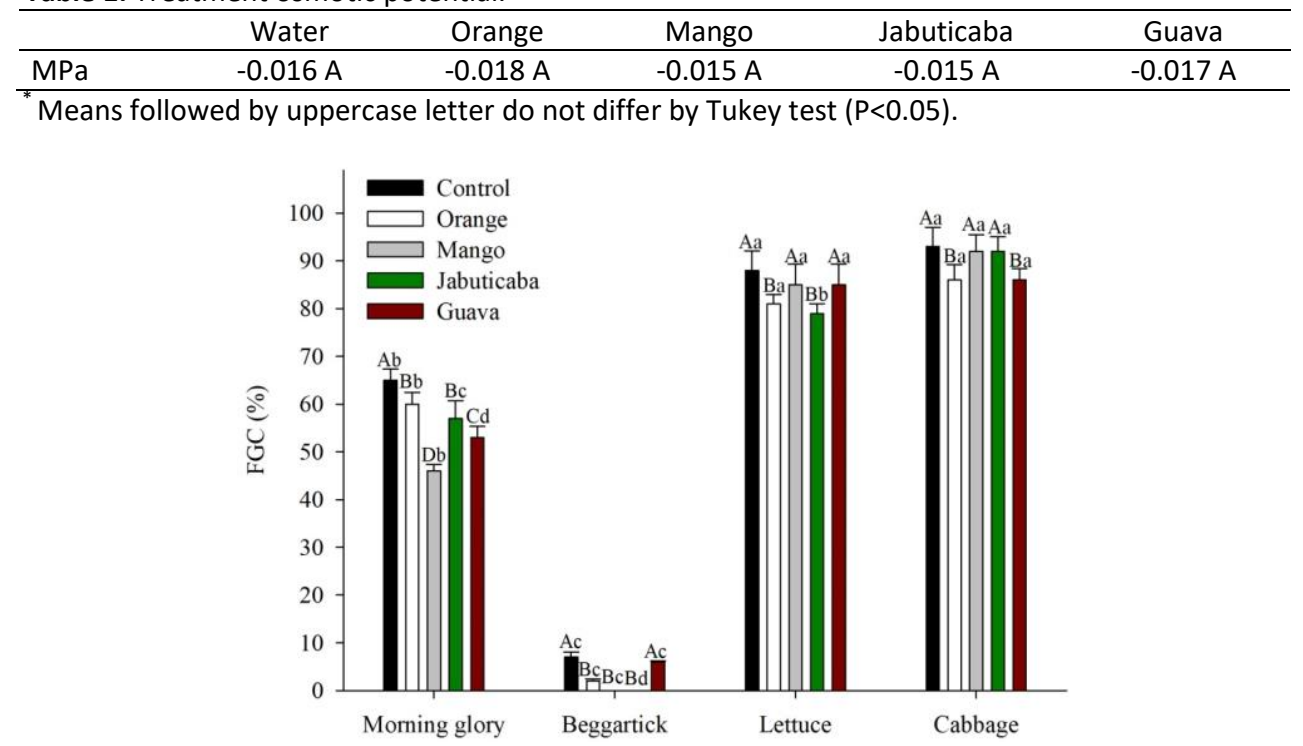

Fig 1. First germination counting (FGC) of the different species submitted to the different allelopathic extracts. Means followed by different uppercase letters in the same species and lowercase in the extracts differ by the Tukey test $(P<0.05)$. Bars: standard deviation.

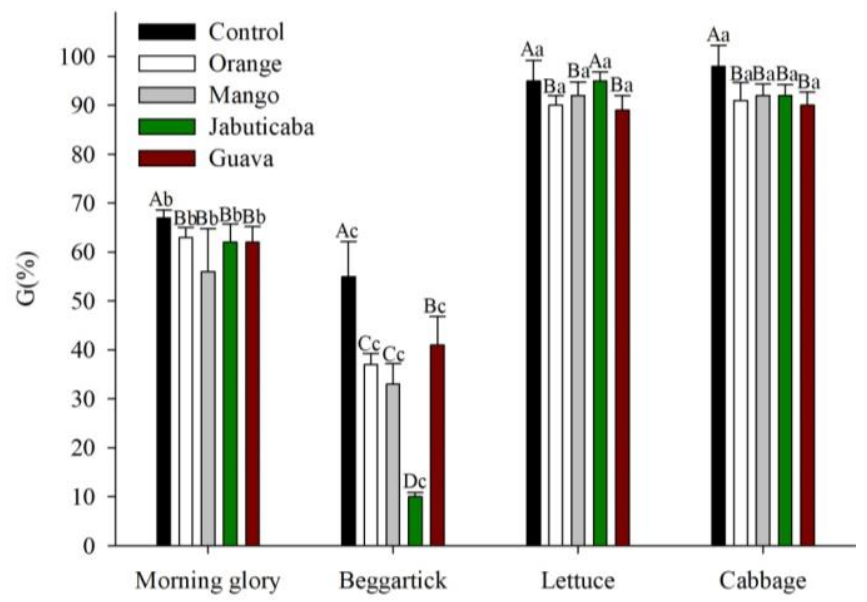

Fig 2. Germination $(G)$ of different species submitted to different allelopathic extracts. Means followed by different uppercase letters in the species and lowercase in the extracts contrast from each other by the Tukey test $(P<0.05)$. Bars: standard deviation.
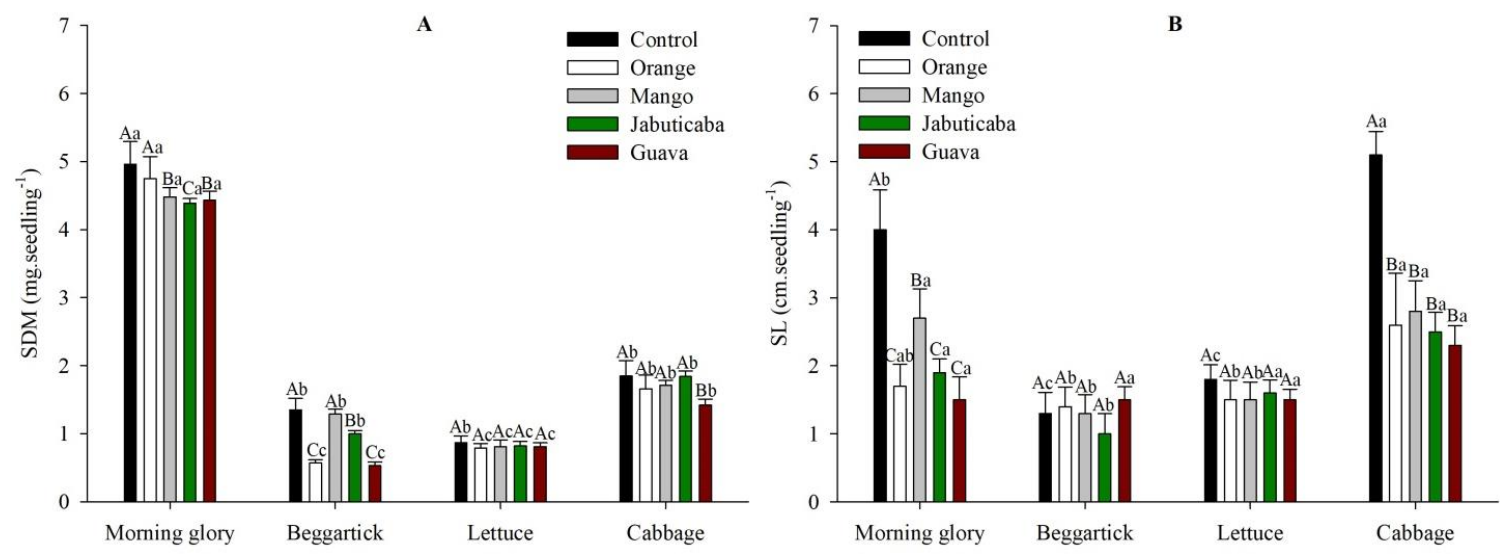

Fig 3. Dry matter (SDM) (A) and length (SL) (B) of seedlings of different species submitted to the effects of different allelopathic extracts. Means followed by different uppercase letters in the species and lowercase letters in the extracts differ by the Tukey test $(P<0.05)$. Bars: standard deviation. 
$2 \mathrm{~mm}$ sieve, and then centrifuged under $3000 \mathrm{rpm}$ during three minutes. The supernatant was collected and the $\mathrm{pH}$ was adjusted to 7.0, according to Prates et al. (2000).

\section{Electric conductivity of allelopathic extracts}

The osmotic potential of each extract was determined using an osmometer (Vapro Optimole model). The mmol. $\mathrm{kg}^{-1}$ values obtained were converted into osmotic potential (MPa) by the Van't Hoff equation (Hillel, 2007).

\section{Germination test}

Following the preliminary germination tests, the concentration was set on $100 \%$ leaf extract. The effect of each extract was evaluated for the germination of different seeds of weed species, namely, morning glory (Ipomoea grandifolia Dammer) and beggartick (Bidens pilosa L.). Aiming to evaluate the possible effects on commercial species, tests with lettuce (Lactuca sativa L.) and cabbage (Brassica oleracea var. capitata L.) seeds were conducted as well.

The seeds were disposed on towel paper sheets, imbibed at the 1 to 2.5 ratio of paper weight to solution weight, on gerbox chambers. Only distilled water was used in the control treatment. The boxes were maintained in germinator chambers at $20{ }^{\circ} \mathrm{C}$. The first germination counting (FGC) and germination (G) evaluations were performed according to the Regra para Análise de Sementes (Rules for Seed Analysis) (Brasil, 2009).

The first germination counting (FGC) was evaluated on the fourth day after seeding for morning glory and beggartick. Lettuce and cabbage were evaluated on the fifth day. Germination was evaluated on the seventh day after seeding for morning glory and lettuce. Beggartick was evaluated on the ninth and cabbage, on the tenth day. The results were expressed in normal seedling percentage (\%).

\section{Seedling development}

After germination, seedling length was measured with the use of a digital caliper and the results were expressed in centimeters. Hereafter, seedlings were desiccate in a forcedair oven $\left(70{ }^{\circ} \mathrm{C}\right)$ until reaching stabilized weight for dry matter determination, expressed in g.seedling ${ }^{-1}$.

\section{Experimental design and statistical analyses}

The experiment was carried out in a completely randomized design (CRD). Four repetitions of 50 seeds were used, except for beggartick, to which eight repetitions of 25 seeds were employed. The data was submitted to variance analysis and the means were compared by the Tukey test, $5 \%$ probability.

\section{Conclusion}

The germination of morning glory and beggartick is mainly affected by the jabuticaba extract. However, lettuce is not affected by it. Mango extract has potential to control morning glory and beggartick in established lettuce and cabbage fields.
Similarly to mango, the extracts of orange, jabuticaba and guava have the potential to control weeds on lettuce established fields. Guava extract is not indicated to control weeds on cabbage cultivated fields.

\section{Acknowledgements}

To the Universidade Federal de Viçosa and the Department of Plant Science (Fitotecnia).

\section{References}

Antonelli J, Lindino CA, Bariccatti RA, de Souza SNM, Nadaletti WC, Cremonez PAE, Rossi E (2016) Allelopathic effect of irrigation with different concentrations of leaf extracts of Jatropha curcas L. on growth Brassica oleracea. Afr J Agric Res. 11:779-782.

Bajwa AA, Chauhan BS, Farooq M, Shabbir A, Adkins SW (2016) What do we really know about alien plant invasion? A review of the invasion mechanism of one of the world's worst weeds. Planta. 244:39-57.

Batish DR, Lavanya K, Pal Singh H, Kohli RK (2007) Rootmediated Allelopathic Interference of Nettle-leaved Goosefoot (Chenopodium murale) on Wheat (Triticum aestivum). J Agron Crop Sci. 193:37-44.

Bezerra APA, Pitombeira JB, Távora JAF, Neto FDCV (2007) Rendimento, componentes da produção e uso eficiente da terra nos consórcios sorgo $x$ feijão-de-corda e sorgo $x$ milho. Rev Cienc Agron. 38:104-108.

Blum A (2011) Plant water relations, plant stress and plant production. In: Plant Breeding for Water-Limited Environments. Springer Science+Business Media, 11-52.

Brasil (2009) Ministério da Agricultura e Reforma Agrária. Regras para análise de sementes. Brasília SNAD/DNDV/CLAV, $398 \mathrm{p}$.

Chauvel B, Guillemin JP, Gasquez J, Gauvrit C (2012) History of chemical weeding from 1944 to 2011 in France: changes and evolution of herbicide molecules. Crop Prot. 42:320-326.

Currey CJ, Lopez RG (2015) Biomass Accumulation and Allocation, Photosynthesis, and Carbohydrate Status of New Guinea Impatiens, Geranium, and Petunia Cuttings Are Affected by Photosynthetic Daily Light Integral during Root Development. J Am Soc Hortic Sci. 140:542-549.

El-Rokiek KG, El-Masry RR, Messiha NK, Ahmed SA (2010) The allelopathic effect of mango leaves on the growth and propagative capacity of purple nutsedge (Cyperus rotundus L.). J Am Sci. 6:151-159.

Glab L, Sowiński J, Bough R, Dayan FE (2017) Allelopathic Potential of Sorghum (Sorghum bicolor (L.) Moench) in Weed Control: A Comprehensive Review. Adv Agron. 145:43-95.

Grisi PU, Ranal MA, Gualtieri SCJ, Santana DG (2012) Allelopathic potential of Sapindus saponaria L. leaves in the control of weeds. Acta Sci Agron. 34:1-9.

Han CM, Pan KW, Wu N, Wang JC, Li W (2008) Allelopathic effect of ginger on seed germination and seedling growth of soybean and chive. Sci Hortic. 116:330-336.

Hillel D (2007) Soil in the Environment: Crucible of Terrestrial Life. Academic Press, New York, 320 p. 
Imatomi M, Novaes P, Matos AP, Gualtieri SCJ, Molinillo JMG, Lacret R, Varela RM, Macías FA (2013) Phytotoxic effect of bioactive compounds isolated from Myrcia tomentosa (Myrtaceae) leaves. Biochem Syst Ecol. 46:29-35.

Islam AKMM, Kato-Noguchi H (2012) Allelopathic potentiality of medicinal plant Leucas aspera. Int J Sust Agric. 4:1-7.

Jabran K, Mahajan G, Sardana V, Chauhan BS (2015) Allelopathy for weed control in agricultural systems. Crop Prot. 72:57-65.

Kato-Noguchi H, Macías FA (2005) Effects of 6-methoxy-2benzoxazolinone on the germination and a-amylase activity in lettuce seeds. J Plant Physiol. 162:1304-1307.

Khaliq A, Matloob A, Khan MB, Tanveer A (2013) Differential suppression of rice weeds by allelopathic plant aqueous extracts. Planta Dan. 31:21-28.

Kilic K, Kara Y, Vaizogullar HE (2016) Allelopathic effects of Lyophyllum platypum mushroom extracts on seed germination of Cynanchum acutum subspecies acutum weed. J Biotechnol. 231: S23.

Krenchinski FH, Albrecht LP, Albrecht AJP, Zonetti PC, Tessele A, Barroso, AAM, Placido, HF (2017) Allelopathic potential of Cymbopogon citratus over beggarticks (Bidens sp.) germination. Aust J Crop Sci. 11:277-283.

Pedrol N, Gonzalez L, Reigosa MJ (2006) Allelopathy and abiotic stress. In: Reigosa, Pedrol, Gonazlez (eds) Allelopathy: a physiological process with ecological implications, $1^{\text {st }}$ ed, Springer, Amsterdam, 171-209.
Pergo ÉM, Ishii-Iwamoto EL (2011) Changes in energy metabolism and antioxidant defense systems during seed germination of the weed species Ipomoea triloba L. and the responses to allelochemicals. Jo Chem Ecol. 37:500-513.

Prates HT, Paes JMV, Pires NDM, Pereira Filho IA, Magalhães PC (2000) Efeito do extrato aquoso de leucena na germinação e no desenvolvimento do milho. Pesq Agr Bras. 35:909-914.

Sahid I, Yusoff N (2014) Allelopathic effects of Chromolaena odorata (L.) King and Robinson and Mikania micrantha H.B.K. on three selected weed species. Aust J Crop Sci. 8:10241028.

Shahrokhi S, Hejazi N, Khodabandeh H, Farboodi M, Faramarzi A (2011) Allelopathic effects of aqueous extracts of pigweed, Amaranthus retroflexus $\mathrm{L}$. organs on germination and growth of five barley cultivars. In: 3rd International Conference on Chemical, Biological and Environmental Engineering Singapore. 20:80-84.

Smith RG, Ryan MR, Menalled FD (2011) Direct and indirect impacts of weed management practices on soil quality. In: Hatfield JL, Sauer TJ (eds) Soil Management: Building a Stable Base for Agriculture, 1st edn. Soil Science Society of America, Madison. 18.

Tsai BY (2008) Effect of peels of lemon, orange, and grapefruit against Meloidogyne incognita. Plant Pathol. Bull. 17:195201.

Turk MA, Tawaha AM (2003). Allelopathic effect of black mustard (Brassica nigra L.) on germination and growth of wild oat (Avena fatua L.). Crop Protect. 22:673-677. 